\title{
Faktor Resiko Penyakit Infeksi Menular Seksual (IMS)
}

\author{
Maria Tuntun \\ Jurusan Analis Kesehatan, Politeknik Kesehatan Tanjungkarang, Indonesia \\ Email: mariatuntun@poltekkes-tjk.ac.id
}

\begin{abstract}
Risk Factors for Sexually Transmitted Infections (STIs). Sexually transmitted infections (STIs) are venereal diseases that can be transmitted by 30 types of pathogens through sexual intercourse. The purpose of this study is to find out the risk factors for STI disease in dr. $\mathrm{H}$ Hospital. Abdul Moeloek Lampung Province in 2012 - 2016. Type of descriptive analytic research with a cross-sectional design. Research place in RSUD dr. H. Abdul Moeloek Lampung Province, in November-December 2017. The population in this study were patients with STIs recorded in the medical record book of 2012-2016 as many as 191 people and a sample of 186 people. The results of the study obtained 4 types of STIs caused by bacteria, namely gonorrhea, syphilis, condyloma, and bartolinitis. The age range of STI patients is 12-62 years, and the most in the 12-25 year age group is 93 people (50\%). The most STI sufferers are men, 100 people $(53.8 \%)$, with the highest education is high school, which is 121 people $(65.1 \%)$, more STI patients who work are 102 people $(54.8 \%)$, and STI sufferers who more from Bandar Lampung, 103 people (55.4\%). Risk factors associated with the type of STI are gender (p-value=0.012) and work (p-value $=0.012)$, while age $(p$-value $=0.718)$, education $(p$-value $=0.368)$, and residence address $(p$-value $=0.088)$ there is no relationship with the type of STI.
\end{abstract}

Keywords: Risk factors, STI

\begin{abstract}
Abstrak: Faktor Resiko Penyakit Infeksi Menular Seksual (IMS). Infeksi menular seksual (IMS) merupakan penyakit kelamin yang dapat ditularkan oleh 30 jenis patogen melalui hubungan seksual. Tujuan penelitian ini yaitu mengetahui faktor resiko penyakit IMS di RSUD dr.H. Abdul Moeloek Provinsi Lampung Tahun 2012 - 2016. Jenis penelitian deskriptif analitik dengan desain cross sectional. Tempat penelitian di RSUD dr. H. Abdul Moeloek Provinsi Lampung, pada bulan November-Desember 2017. Populasi pada penelitian ini adalah penderita IMS yang tercatat dalam buku rekam medik tahun 2012-2016 sebanyak 191 orang, dan sampel sebanyak 186 orang. Hasil penelitian mendapatkan 4 jenis IMS yang disebabkan oleh bakteri, yaitu gonore, sifilis, kondiloma dan bartolinitis. Rentang umur penderita IMS yaitu 12-62 tahun, dan terbanyak pada kelompok umur 12-25 tahun yaitu 93 orang (50\%). Penderita IMS terbanyak adalah laki-laki yaitu 100 orang $(53,8 \%)$, dengan pendidikan terbanyak adalah SLTA yaitu 121 orang $(65,1 \%)$, penderita IMS yang bekerja lebih banyak yaitu 102 orang $(54,8 \%)$, dan penderita IMS yang berasal dari Bandar Lampung lebih banyak yaitu 103 orang $(55,4 \%)$. Faktor resiko yang berhubungan dengan jenis IMS yaitu jenis kelamin ( $p$-value $=0,012)$ dan pekerjaan $(p$-value $=0,012)$, sedangkan umur $(p$ value $=0,718)$, pendidikan $(p$-value $=0,368)$, dan alamat tempat tinggal $(p$-value $=0,088)$ tidak ada hubungan dengan jenis IMS.
\end{abstract}

Kata kunci: Faktor resiko, IMS

Infeksi menular seksual (IMS) merupakan infeksi yang ditularkan memlalui hubungan seksual, yang popular disebut penyakit kelamin. Semua tehnik hubungan seks lewat vagina, dubur atau mulut dapat menjadi wahana penularan penyakit kelamin. Penyebab infeksi tersebut diantaranya adalah bakteri (misalnya gonore, sifilis), jamur, virus (misalnya herpes, HIV), atau parasit (misalnya kutu), penyakit ini dapat menyerang pria maupun wanita (UNESCO, 2012).
IMS menyebabkan infeksi alat reproduksi yang harus dianggap serius. Bila tidak diobati secara tepat, infeksi dapat menjalar, sakit berkepanjangan, kemandulan bahkan kematian. Remaja perempuan perlu menyadari bahwa risiko untuk terkena IMS lebih besar daripada laki-laki sebab alat reproduksi perempuan lebih rentan, dan seringkali berakibat lebih parah karena gejala awal tidak segera dikenali, sedangkan penyakit berlanjut ke tahap lebih parah (UNESCO, 2012).

Penyakit IMS yang sering terjadi di masyarakat diantaranya gonore, sifilis, klamidia, 
kondiloma, bakterial vaginosis dan lain-lain. Penyakit gonore disebabkan bakteri Neisseria Gonorrheae. Pada laki-laki dikenal sebagai kencing nanah, dengan gejala keluar cairan kental berwarna kekuningan dari alat kelamin, nyeri di perut bagian bawah. Pada perempuan sering tanpa gejala. Komplikasi yang mungkin terjadi, diantaranya radang panggul pada perempuan, kemungkinan terjadi kemandulan baik pada perempuan atau laki-laki, infeksi mata pada bayi baru lahir yang dapat menyebabkan kebutaan, kehamilan ektopik (di luar kandungan) dan memudahkan penularan infeksi HIV (Dailli, 2009). Penyakit sifilis disebut juga raja singa, disebabkan bakteri Treponema palidum. Gejala yag timbul tampak luka tunggal, menonjol dan tidak nyeri, bintil/bercak merah di tubuh yang hilang dengan sendirinya, dan sering limfadenopati. Komplikasinya kerusakan pada otak dan jantung, pada kehamilan dapat ditularkan pada bayi, keguguran atau lahir cacat dan memudahkan penularan infeksi HIV (Holmes, 2005). Penyakit klamidia disebabkan bakteri Chlamydia trachomatis. Infeksi ini biasanya kronis, karena $70 \%$ perempuan pada awalnya tidak merasakan gejala apapun sehingga tidak memeriksakan diri. Gejalanya yaitu keluar cairan vagina/penis encer berwarna putih kekuningan, nyeri di rongga panggul, pendarahan setelah hubungan seksual (pada perempuan). Komplikasi yang terjadi biasanya menyertai gonore, penyakit radang panggul, kemandulan akibat perlekatan pada saluran falopian, kehamilan ektopik (diluar kandungan), infeksi mata dan radang paru-paru (pneumonia) pada bayi baru lahir dan memudahkan penularan infeksi HIV (Dailli, 2009).

Menurut WHO (2010, dalam CDC) kasus IMS terbanyak terjadi di Papua New Guenia, dengan jumlah kasus lebih dari 2 juta kasus IMS yang didiagnosa per tahunnya, seperti sifilis $26 \%$, gonoroe $34 \%$, dan bakterial vaginosis $57 \%$. Kasus IMS meningkat dari tahun ke tahun, hal ini ditunjukkan oleh data WHO (2013) bahwa telah terjadi penularan IMS lebih dari satu juta orang setiap harinya, dan diperkirakan sekitar 500 juta orang per tahun telah terinfeksi IMS, seperti sifilis, gonoroe, klamidia dan trikomoniasis. Di Amerika Serikat (2008) terdapat sekitar 20 juta kasus baru IMS, dan jumlah wanita yang menderita infeksi klamidia 3 kali lebih tinggi dari laki laki. Dari seluruh wanita yang menderita infeksi klamidia, golongan umur yang memberikan kontribusi yang besar ialah umur 15-24 tahun (CDC, 2013).

Di Indonesia (2009) terdapat beberapa kota dengan kasus IMS yang tinggi seperti di
Surabaya dengan kasus sifilis $29,8 \%$, gonoroe $22,8 \%$, dan bakterial vaginosis $37,7 \%$. Jakarta dengan kasus sifilis $29,2 \%$, gonoroe $32,8 \%$, dan bakterial vaginosis $22,7 \%$. Bandung dengan jumlah kasus sifilis $25,2 \%$, gonoroe $47,4 \%$, dan bakterial vaginosis $36,5 \%$. Di Medan dengan kasus sifilis 3,4\% dan bakterial vaginosis 7,3\% (Adhitama, 2010).

Data STBP (2007) mencatat bahwa cakupan program kesehatan pada kelompok WPSTL (Wanita Pekerja Sek Tidak Langsung) masih rendah, sehingga jumlah kasus IMS pada kelompok WPSTL masih cukup tinggi yaitu untuk kasus gonore $17,7 \%$, sifilis $1,8 \%$, dan klamidia sebesar 30,8\% (Dirjen PP\&PL, 2014).

Lebih dari 30 jenis patogen dapat ditularkan melalui hubungan seksual dengan manifestasi klinis bervariasi menurut jenis kelamin dan umur. Hubungan seksual merupakan jalur utama penularan infeksi menular seksual, tetapi bayi/janin dapat tertular dari ibu pada saat dalam kandungan atau saat kelahiran (Kemenkes, 2011). Gonore, sifilis dan Klamidia, adalah tiga penyakit menular seksual yang disebabkan oleh bakteri, dan pengobatannya dapat disembuhkan dengan antibiotik. Pada saat ini, banyak kejadian resistensi kuman penyebab infeksi menular seksual terhadap beberapa antibiotik, sehingga menimbulkan masalah dalam pengobatan infeksi menular seksual (WHO, 2016).

Peningkatan kejadian IMS dipengaruhi oleh beberapa faktor yang diantaranya adalah perubahan demografik seperti pertumbuhan jumlah penduduk yang sangat tinggi, pergerakan masyarakat yang meningkat karena pekerjaan ataupun pariwisata, kemajuan teknologi berbasis IT (Informasi Teknologi) dan peningkatan sosial ekonomi. Utamanya kemajuan teknologi berbasis IT menyebabkan dunia tanpa batas, yang dapat mengakibatkan perubahan-perubahan demografi sehingga terjadi pergeseran nilai-nilai moral dan agama pada masyarakat. Faktor lain yang juga mempengaruhi peningkatan IMS adalah kelalaian negara dalam memberi pendidikan kesehatan dan seks kepada masyarakat, fasilitas kesehatan yang belum memadai dan banyak kasus asimptomatik sehingga pengidap merasa tidak sakit, namun dapat menularkan penyakitnya kepada orang lain (Djuanda, 2010). Infeksi itu sendiri dapat terjadi pada siapa saja, dari lapisan masyarakat manapun dan mulai dari usia muda hingga tua. Dengan memahami gambaran infeksi menular seksual yang terjadi pada masyarakat dan distribusi populasi berisiko tinggi terhadap infeksi ini akan sangat membantu upaya pencegahan penularan IMS dan pengobatan dini terhadap pengidapnya (Kemenkes, 2011). 
Dinas Kesehatan Kota Bandar Lampung tahun 2010, melaporkan kasus gonoroe sebanyak 63 kasus, non gonoroe sebanyak 48 kasus, dan penyakit kelamin lain sebanyak 345 kasus (Dinkes Provinsi Lampung, 2010), dan tahun 2015 terjadi peningkatann kasus IMS, yaitu sebanyak 632 kasus (Dinkes Provinsi Lampung, 2015). Tingginya kasus IMS sebagian ditangani di RSUD dr. H. Abdul Moeloek. Rumah sakit ini merupakan fasilitas kesehatan tingkat lanjut yang menjadi rujukan dari fasilitas kesehatan tingkat pertama. Pasien dengan penyakit IMS dilayani di Poli penyakit kulit dan kelamin RSUD dr. H. Abdul Moeloek. Pasien-pasien ini berasal dari rujukan rumah sakit tipe $\mathrm{C}$ atau pasien datang sendiri sebagai pasien umum. Tujuan dilakukan penelitian ini yaitu mengetahui faktor resiko penyakit IMS di RSUD dr.H. Abdul Moeloek Provinsi Lampung Tahun 2012-2016. Faktor resiko terdiri dari umur, jenis kelamin, pendidikan, pekerjaan, dan tempat tinggal penderita IMS.

\section{METODE}

Jenis penelitian ini adalah deskriptif analitik dengan desain cross sectional. Penelitian dilakukan di Poli Rawat Jalan Ruang Penyakit Kulit dan Kelamin RSUD dr. H. Abdul Moeloek Provinsi Lampung, bulan November-Desember 2016.

\section{A. ANALISIS UNIVARIAT}

Tabel 1. Jumlah Penderita Berdasarkan Jenis IMS Tahun 2012-2016

\begin{tabular}{lrrrrrrrr}
\hline \multirow{2}{*}{ Jenis IMS } & \multicolumn{9}{c}{ Tahun } & \multirow{2}{*}{ Jlh } & \multirow{2}{*}{ \% } \\
\cline { 2 - 6 } & $\mathbf{2 0 1 2}$ & $\mathbf{2 0 1 3}$ & $\mathbf{2 0 1 4}$ & $\mathbf{2 0 1 5}$ & $\mathbf{2 0 1 6}$ & & 55 & 29.6 \\
Gonore & 4 & 12 & 16 & 11 & 12 & 4 & 2.2 \\
Sifilis & 0 & 3 & 0 & 0 & 1 & 52 & 118 & 63.4 \\
Kondiloma & 17 & 22 & 19 & 13 & 0 & 9 & 4.8 \\
Bartolinitis & 1 & 4 & 1 & 0 & 24 & 68 & 186 & 100 \\
\hline Jumlah & 22 & 41 & 36 & & & & \\
\hline
\end{tabular}

Data pada tabel 1 menunjukkan jumlah penderita IMS selama 5 tahun (2012-2016) sebanyak 186 penderita. Jumlah penderita IMS terbanyak pada tahun 2016 yaitu sebanyak 68 penderita, dan yang paling sedikit pada tahun 2012 yaitu sebanyak 22 penderita. Jenis IMS
Populasi penelitian adalah seluruh penderita IMS yang tercatat dalam buku rekam medik di Poli Rawat Jalan Ruang Penyakit Kulit dan Kelamin RSUD dr. H. Abdul Moeloek Provinsi Lampung pada tahun 2012-2016. Sampel dalam penelitian ini diambil dari populasi yang didiagnosa menderita salah satu jenis IMS yang disebabkan oleh bakteri diantaranya gonore, sifilis, kondiloma, atau bartolinitis, yaitu sebanyak 186 orang.

Pengumpulan data dilakukan dengan cara observasi data penderita IMS pada buku rekam medik meliputi nama/inisial penderita, umur, jenis kelamin, pendidikan, pekerjaan, tempat tinggal dan jenis IMS periode tahun 2012-2016. Pengolahan data secara univariat dilakukan untuk melihat karakteristik responden baik umur, jenis kelamin, pendidikan, pekerjaan, tempat tinggal maupun jenis IMS, sedangkan pengolahan data secara bivariat untuk melihat hubungan antara jenis IMS dengan faktor resiko. Data diolah secara statistik dengan uji chi square.

\section{HASIL}

Dalam penelitian ini didapatkan populasi sebanyak 191 penderita IMS, dan yang menjadi sampel sebanyak 186 penderita IMS, karena ada 5 penderita IMS yang tidak lengkap datanya dalam rekam medik. Penyajian data dilakukan dalam analisis univariat dan bivariat sebagai berikut: 
Tabel 2. Distribusi Frekuensi Berdasarkan Karakteristik Penderita IMS

\begin{tabular}{llcc}
\hline Variabel & & Frekuensi & \% \\
\hline Jenis & Perempuan & 86 & 46.2 \\
Kelamin & Laki-Laki & 100 & 53.8 \\
\hline Kelompok & $12-25$ & 93 & 50.0 \\
Umur & $26-45$ & 79 & 42.5 \\
(tahun) & $46-65$ & 14 & 7.5 \\
\hline Pendidikan & SD & 3 & 1.6 \\
& SLTP & 31 & 16.7 \\
& SLTA & 121 & 65.1 \\
& Perguruan Tinggi & 31 & 16.7 \\
\hline Pekerjaan & Bekerja & 102 & 54.8 \\
& Tidak Bekerja & 38 & 20.4 \\
& Pelajar/Mahasiswa & 46 & 24.7 \\
\hline Alamat & Bandar Lampung & 103 & 55.4 \\
(Tempat & Luar Bandar & 83 & 44.6 \\
Tinggal) & Lampung & & \\
\hline
\end{tabular}

Berdasarkan tabel 2 jumlah penderita IMS terbanyak adalah laki-laki yaitu 100 orang $(53,8 \%)$, dibandingkan perempuan sebanyak 86 orang $(46,2 \%)$. Jumlah penderita IMS terbanyak pada kelompok umur 12-25 tahun yaitu 93 orang (50\%), diikuti kelompok umur 26-45 tahun sebanyak 79 orang $(42,5 \%)$, dan yang paling sedikit pada kelompok umur 46-65 tahun yaitu 14 orang (7,5\%). Sebanyak 121 penderita IMS $(65,1 \%)$ berpendidikan SLTA, dan hanya 3 orang $(1,6 \%)$ yang berpendidikan SD. Penderita IMS dengan pendidikan Perguruan Tinggi sebanyak 31 orang $(16,7 \%)$. Penderita IMS yang bekerja lebih banyak yaitu 102 orang $(54,8 \%)$, dibanding yang tidak bekerja yaitu 38 orang $(20,4 \%)$. Dalam penelitian ini didapatkan data penderita IMS yang masih pelajar/mahasiswa, yaitu 46 orang $(24,7 \%)$. Jumlah penderita IMS yang berasal dari Bandar Lampung lebih banyak yaitu 103 orang $(55,4 \%)$, dibandingkan yang berasal dari luar Bandar Lampung yaitu 83 orang $(44,6 \%)$.

\section{B. ANALISIS BIVARIAT}

Analisis bivariat menggunakan uji Chi square dilakukan untuk mengetahui hubungan antara faktor resiko dengan jenis IMS. Faktor resiko terdiri dari umur, jenis kelamin, pendidikan, pekerjaan, dan alamat (tempat tinggal) penderita IMS, sedangkan jenis IMS yang disebabkan oleh bakteri meliputi gonore, sifilis, kondiloma dan bartolinitis. Hasilnya dapat dilihat pada tabel di bawah ini.

Tabel 3. Hubungan Jenis IMS dengan Faktor Resiko

\begin{tabular}{|c|c|c|c|c|c|c|c|c|c|}
\hline \multirow{3}{*}{ Variabel } & \multicolumn{8}{|c|}{ Jenis IMS } & \multirow{3}{*}{$\begin{array}{c}p- \\
\text { value }\end{array}$} \\
\hline & \multicolumn{2}{|c|}{ Gonore } & \multicolumn{2}{|c|}{ Sifilis } & \multicolumn{2}{|c|}{ Kondiloma } & \multicolumn{2}{|c|}{ Bartolinitis } & \\
\hline & $\mathbf{n}$ & $\%$ & $\mathbf{n}$ & $\%$ & $\mathbf{n}$ & $\%$ & $\mathbf{n}$ & $\%$ & \\
\hline \multicolumn{10}{|l|}{ Jenis kelamin } \\
\hline Perempuan & 22 & 25,6 & 0 & 0,0 & 56 & 65,1 & 8 & 9,3 & \multirow{2}{*}{0,012} \\
\hline Laki-laki & 33 & 33,0 & 4 & 4,0 & 62 & 62,0 & 1 & 1,0 & \\
\hline \multicolumn{10}{|c|}{ Kelompok Umur (tahun) } \\
\hline $12-25$ & 31 & 33,3 & 3 & 3,2 & 55 & 59,1 & 4 & 4,3 & \multirow{3}{*}{0,718} \\
\hline $26-45$ & 20 & 25,3 & 1 & 1,3 & 53 & 67,1 & 5 & 6,3 & \\
\hline $46-65$ & 4 & 28,6 & 0 & 0,0 & 10 & 71,4 & 0 & 0,0 & \\
\hline \multicolumn{10}{|l|}{ Pendidikan } \\
\hline SD & 1 & 33,3 & 0 & 0,0 & 2 & 66,7 & 0 & 0,0 & \multirow[t]{4}{*}{0,368} \\
\hline SLTP & 14 & 45,2 & 0 & 0,0 & 16 & 51,6 & 1 & 3,2 & \\
\hline SLTA & 29 & 24,0 & 4 & 3,3 & 80 & 66,1 & 8 & 6,6 & \\
\hline PT & 11 & 35,5 & 0 & 0,0 & 20 & 64,5 & 0 & 0,0 & \\
\hline \multicolumn{10}{|l|}{ Pekerjaan } \\
\hline Bekerja & 30 & 29,4 & 4 & 3,9 & 66 & 64,7 & 2 & 2,0 & \multirow[t]{3}{*}{0,01} \\
\hline Tidak bekerja & 4 & 10,5 & 0 & 0,0 & 29 & 76,3 & 5 & 13,2 & \\
\hline Pelajar/mahasiswa & 21 & 45,7 & 0 & 0,0 & 23 & 50,0 & 2 & 4,3 & \\
\hline \multicolumn{10}{|c|}{ Alamat (Tempat tinggal) } \\
\hline Bandar Lampung & 34 & 33,0 & 0 & 0,0 & 63 & 61,2 & 6 & 5,8 & \multirow[t]{2}{*}{0,088} \\
\hline Luar Bandar Lampung & 21 & 25,3 & 4 & 4,8 & 55 & 66,3 & 3 & 3,6 & \\
\hline
\end{tabular}

Pada tabel 3 dapat dilihat hasil uji chi square menunjukkan bahwa faktor jenis kelamin (nilai $p=0,012$ ) dan pekerjaan (nilai $p=0,01$ ) mempunyai hubungan yang bermakna dengan jenis IMS. Sedangkan faktor kelompok umur (nilai $p=0,718$ ), pendidikan (nilai $p=0,368$ ), dan 
alamat/tempat tinggal (nilai $p=0,088$ ) tidak mempunyai hubungan yang bermakna dengan jenis IMS, karena nilai $p>0,05$.

\section{PEMBAHASAN}

\section{A. ANALISIS UNIVARIAT}

Penderita IMS dalam penelitian ini sebanyak 186 orang. Dari jumlah tersebut, jenis IMS yang disebabkan oleh bakteri terbanyak adalah kondiloma yaitu 118 orang $(63,4 \%)$, diikuti gonore yaitu 55 orang $(29,6 \%)$, dan bartolinitis sebanyak 9 orang $(4,8 \%)$, sedangkan yang paling sedikit yaitu sifilis hanya 4 orang (2,2\%). Dalam kurun waktu tahun 2012-2016 didapatkan jenis IMS seperti kondiloma, gonore dan bartolinitis, sedangkan kasus sifilis hanya ada pada tahun 2013 dan 2016 saja. Hal ini dapat disebabkan karena RSUD dr.H. abdul Moeloek merupakan rumah sakit rujukan tingkat provinsi. Penderita IMS yag berobat merupakan penderita rujukan dari fasilitas kesehatan tingkat pertama.

Penderita IMS terbanyak ada pada kelompok umur 12-25 tahun yaitu 93 orang (50\%), diikuti kelompok umur 26-45 tahun yaitu sebanyak 79 orang $(42,5 \%)$. Tidak ada penderita IMS yang berusia kurang dari 12 tahun atau lebih dari 62 tahun. Keadaan ini sama seperti hasil penelitian Dyna (2014) di Puskesmas Bandar Baru, Kecamatan Sibolangit, Kabupaten Deli Serdang, yang mendapatkan penderita IMS berada pada rentang umur 15-45 tahun. Jumlah penderita IMS pada rentang umur ini (20-40 tahun) juga didapatkan dalam penelitian yang dilakukan Handayani (2013) di Puskesmas Panjang Bandar Lampung sebanyak 95,1\%. Laporan survey terpadu biologis dan perilaku (STBP) tahun 2007 mendapatkan bahwa umur pertama kali melakukan perilaku yang beresiko terkena IMS adalah dibawah 20 tahun. Umur penderita IMS dalam penelitian ini sebagian besar berada pada masa produktif, dimana aktivitas seksualnya sedang meningkat. Aktivitas seksual yang tinggi dan tanpa terkendali merupakan pintu masuk terjangkitnya IMS pada orang tersebut. Hal ini sesuai dengan temuan pada survey terpadu biologis dan perilaku yang dilaksanakan oleh Departemen Kesehatan (Depkes, 2010).

Dalam penelitian ini didapatkan penderita IMS terbanyak berjenis kelamin laki-laki yaitu 100 orang $(53,8 \%)$ dibandingkan perempuan hanya 86 orang $(46,2 \%)$. Hal ini sejalan dengan penelitian Santoso (2015) yang mendapatkan penderita IMS laki-laki $(78,5 \%)$ lebih banyak dibandingkan perempuan $(72,7 \%)$ dan tidak sejalan dengan penelitian Dyna (2014) dan Sridana (2014) yang mendapatkan penderita IMS perempuan lebih banyak dibandingkan laki-laki. Menurut Azwar S (2010) laki-laki dan perempuan mempunyai resiko yang sama untuk terkena IMS. Menurut Fitch dan Cox sebenarnya terdapat cara pandang yang menyebutkan bahwa prilaku seksual murni karena dorongan biologis, dimana kebanyakan laki-laki lebih menginginkan seks dari pada wanita. Laki-laki mengenal dunianya melalui penjelajahan dan dorongan fisik, emosi bahkan dorongan seksual nya lebih besar dari perempuan (Azwar, 2010).

Berdasarkan tingkat pendidikan, jumlah penderita IMS terbanyak adalah berpendidikan SLTA yaitu 121 orang $(65,1 \%)$. Jumlah penderita IMS yang berpendidikan SLTP sama banyak dengan yang berpendidikan Perguruan Tinggi, yaitu 31 orang $(16,7 \%)$. Jumlah penderita IMS yang paling sedikit yaitu berpendidikan SD sebanyak 3 orang $(1,6 \%)$. Hasil penelitian ini sejalan dengan penelitian Dyna (2014) yang mendapatkan bahwa penderita IMS terbanyak pada jenjang SLTA yaitu $79,4 \%$. Hasil penelitian ini tidak sejalan dengan hasil penelitian Handayani (2013) dan Febiyantin (2014), yang mendapatkan bahwa kejadian IMS lebih banyak pada penderita dengan jenjang pendidikan SLTP. Dalam penelitian ini didapatkan penderita IMS dengan jenjang pendidikan perguruan tinggi (PT) yang menderita gonore sebanyak $35,5 \%$ dan kondiloma $64,5 \%$. Umumnya berjenis kelamin laki-laki. Banyaknya penderita IMS yang berpendidikan Perguruan Tinggi sangat mengkhawatirkan, karena pendidikan yang tinggi harusnya berkorelasi dengan pengetahuan yang lebih baik dan wawasan yang luas, sehingga dapat berfikir positif untuk tidak melakukan aktifitas seksual yang terlarang (Notoatmodjo, 2003).

Jumlah penderita IMS yang bekerja lebih banyak yaitu 102 orang $(54,8 \%)$, dibanding yang tidak bekerja yaitu 38 orang $(20,4 \%)$. Penderita IMS yang tidak bekerja dalam penelitian ini seluruhnya berstatus sebagai ibu rumah tangga. Dalam penelitian ini didapatkan penderita IMS yang masih pelajar/mahasiswa, yaitu 46 orang $(24,7 \%)$. Jumlah ini cukup banyak, mengingat pelajar/ mahasiswa sebenarnya belum berumah tangga, sehingga seharusnya belum melakukan hubungan seksual. Tetapi remaja selalu berusaha mencari lebih banyak informasi mengenai seks dari berbagai sumber seperti teman sebaya, bukubuku atau menonton film, bahkan hingga mengadakan percobaan dengan jalan masturbasi, bercumbu atau bersenggama (Azwar, 2010). Hal 
ini didukung hasil penelitian Naully (2018), yaitu didapatkan 32\% remaja usia 15-19 tahun pernah melakukan hubungan seksual, bahkan bergantiganti pasangan sebanyak $17 \%$.

Jumlah penderita IMS yang berasal dari Bandar Lampung lebih banyak yaitu 103 orang $(55,4 \%)$, dibandingkan yang berasal dari luar Bandar Lampung yaitu 83 orang $(44,6 \%)$. Penderita IMS yang berobat di rumah sakit RSUD dr.H.Abdul Moeloek seluruhnya berasal dari provinsi Lampung, dan rumah sakit ini merupakan rumah sakit rujukan tertinggi di provinsi Lampung.

\section{B. ANALISIS BIVARIAT}

Hasil analisis bivariat antara faktor resiko yang terdiri dari umur, jenis kelamin, pendidikan, pekerjaan dan alamat tempat tinggal dengan jenis IMS didapatkan adanya hubungan yang bermakna yaitu pada faktor resiko jenis kelamin dan pekerjaan terhadap jenis IMS, karena didapatkan nilai $p<0,05$. Sedangkan faktor resiko umur, pendidikan, dan alamat tempat tinggal tidak ada hubungan yang bermakna terhadap jenis IMS, karena didapatkan nilai $p>0,05$.

Ada hubungan yang bermakna antara jenis IMS dengan jenis kelamin, menunjukkan bahwa baik laki-laki maupun perempuan mempunyai resiko untuk terkena IMS. Hasil penelitian ini mendapatkan bahwa penderita gonore lebih banyak laki-laki (33\%) dibandingkan perempuan $(25, \%)$, tetapi kondiloma $(65,1 \%)$ dan bartolinitis $(9,3 \%)$ lebih banyak perempuan, sedangkan penderita sifilis $(4,0 \%)$ semuanya laki-laki. Hasil analisis chi square antara jenis IMS dengan jenis kelamin penderita IMS didapatkan nilai $\mathrm{p}=0,012$, artinya nilai $\mathrm{p}<0,05$ maka disimpulkan bahwa ada hubungan antara jenis IMS dengan jenis kelamin penderita IMS. Hasil ini tidak sejalan dengan penelitian Santoso (2015) yang mendapatkan bahwa tidak ada hubungan antara jenis kelamin dengan perilaku yang beresiko terkena IMS.

Hasil analisis chi square antara jenis IMS dengan pekerjaan penderita IMS didapatkan nilai $\mathrm{p}=0,01$ maka disimpulkan ada hubungan antara jenis IMS dengan pekerjaan. Dalam penelitian ini penderita gonore lebih banyak diderita oleh pelajar/mahasiswa $(45,7 \%)$ dibandingkan dengan yang bekerja $(29,4 \%)$ atau tidak bekerja $(10,5 \%)$. Sifilis diderita oleh penderita IMS yang sudah bekerja. Kondiloma (76,3\%) dan bartolinitis $(13,2 \%)$ paling banyak diderita oleh penderita IMS yang tidak bekerja. Penderita IMS yang tidak bekerja dalam penelitian ini merupakan ibu rumah tangga.
Hasil analisis chi square antara jenis IMS dengan umur penderita IMS didapatkan nilai $\mathrm{p}=0,718$ maka disimpulkan tidak ada hubungan antara jenis IMS dengan umur penderita IMS. Kelompok umur 12-25 tahun merupakan kelompok umur yang paling banyak menderita gonore $(33,3 \%)$, sifilis $(3,2 \%)$, dan kondiloma $(59,1 \%)$ dibandingkan kelompok umur 26-45 tahun dan kelompok umur 46-65 tahun. Hasil penelitian ini tidak sejalan dengan penelitian Sridana (2014) yang mendapatkan kelompok umur 25-49 tahun lebih banyak yang menderita IMS $(70,4 \%)$.

Tingkat pendidikan mencerminkan pengetahuan yang dimiliki seseorang. Dalam penelitian ini didapatkan bahwa penderita IMS terbanyak dengan pendidikan SLTA (65.1\%), hal ini tidak sejalan dengan penelitian Febiyantin yang mendapatkan penderita IMS terbanyak berpendidikan SLTP $(46,7 \%)$. Hasil penelitian ini mempunyai kesamaan dengan hasil penelitian Febiyantin (2014), Namun mempuyai kesamaan yaitu didapatkan nilai $p>0,05$ sehingga dapat disimpulkan tidak ada hubungan antara pendidikan dengan jenis IMS. Pendidikan penderita IMS terendah adalah SD dan tertinggi adalah perguruan tinggi (PT). Penderita gonore (29 orang), kondiloma (80 orang), dan bartolinitis ( 8 orang), paling banyak dengan jenjang pendidikan SLTA, dan penderita sifilis seluruhnya berpendidikan SLTA.

Hasil analisis chi square antara jenis IMS dengan alamat (tempat tinggal) penderita IMS didapatkan nilai $p=0,088$ maka dapat disimpulkan bahwa tidak ada hubungan antara jenis IMS dengan alamat (tempat tinggal) penderita IMS. Dalam penelitian ini didapatkan bahwa penderita sifilis seluruhnya berasal dari luar Kota Bandar Lampung. Tidak adanya penderita sifilis dari Bandar Lampung, bukan berarti tidak ada kasus sifilis. Hal ini dimungkinkan penderita sifilis menjalani pengobatannya di puskesmas kota Bandar Lampung yang mempunyai program penanganan IMS. Berdasarkan alamat tempat tinggal, penderita gonore dan bartolonitis terbanyak berasal dari Kota Bandar Lampung.

\section{SIMPULAN}

Simpulan penelitian ini yaitu didapatkan penderita IMS seluruhnya sebanyak 186 orang, dengan jenis IMS yang disebabkan bakteri yaitu gonore, sifilis, kondiloma dan bartolinitis. Rentang umur penderita IMS terbanyak pada kelompok umur 12-25 tahun. Penderita IMS 
terbanyak berjenis kelamin laki-laki yaitu 100 orang $(53,8 \%)$, jenjang pendidikan penderita IMS terbanyak adalah SLTA yaitu 121 orang $(65.1 \%)$, penderita IMS yang bekerja lebih banyak yaitu 102 orang $(54,8 \%)$, dan lebih banyak penderita IMS yang berasal dari Bandar Lampung yaitu 103 orang $(55,4 \%)$.

Hasil uji chi square menunjukkan ada hubungan jenis IMS dengan jenis kelamin (nilai $p=0,012$ ) dan pekerjaan (nilai $p=0,01$ ), tetapi tidak ada hubungan jenis IMS dengan kelompok umur (nilai $p=0,718$ ), pendidikan (nilai $p=0,368$ ), dan tempat tinggal (nilai $p=0,088$ ).

\section{DAFTAR PUSTAKA}

Adhitama. 2010. Data Kasus Infeksi Menular Seksual. PT. Gramedia Pustaka Utama, Jakarta: 2010.

Azwar, S. 2010. Sikap manusia, teori dan pengukuran. Yogyakarta: Pustaka Fajar.

CDC (Centers of Disease Control and Prevention). 2013. Sexually Transmitted Disease.

USA. https://www.cdc.gov/std/general/other.htm

Daili, S.F. 2009. Gonore, InfeksiMenular Seksual, Edisi 4. Jakarta: Balai Penerbitan FKUI.

Departemen Kesehatan RI. 2010. Analisis kecenderungan perilaku berisiko terhadap HIV di Indonesia. Hasil Surveilans Terpadu Biologis dan Perilaku (STBP) tahun 2007. Dirjen Pengendalian Penyakit dan Penyehatan Lingkungan. Jakarta: Departemen Kesehatan RI.

Dinas Kesehatan Propinsi Lampung. 2010. Profil Kesehatan Propinsi Lampung. Lampung: Dinas Kesehatan Propinsi Lampung

Dinas Kesehatan Propinsi Lampung. 2015. Profil Kesehatan Propinsi Lampung. Lampung: Dinas Kesehatan Propinsi Lampung

Direktorat Jenderal PP \& PL. 2014. Statistik Kasus HIV/AIDS di Indonesia. Jakarta: Departemen Kesehatan Republik Indonesia.

Djuanda, Adhi, Hamzah, Mochtar, Aisah, Siti (Ed). 2010. Ilmu Penyakit Kulit dan Kelamin. Jakarta: Fakultas Kedokteran UI.

Dyna, S., Rasmaliah, Jemadi. (2014). Karakteristik Penderita Infeksi Menular Seksual Di Wilayah Kerja Puskesmas Bandar Baru Tahun 2013. Jurnal Gizi, Kesehatan Reproduksi Dan Epidemiologi $1(2)$.

https://jurnal.usu.ac.id/Gkre/Article/View/ 7591.

\section{SARAN}

Tingginya kasus IMS yang didapatkan dalam penelitian ini harus mendapat perhatian, terutama penangan pada penderitanya yang masih dalam usia produktif, seperti melakukan penyuluhan tentang bahaya penyakit IMS dan pendampingan pada remaja penderita IMS, agar dapat menjalani kehidupan dengan lebih baik.

Febiyantin, C., S, Kriswiharsi K. 2014. FaktorFaktor Yang Berhubungan Dengan Kejadian Infeksi Menular Seksual (IMS) Pada Wanita Pekerja Seksual (WPS) Usia 20-24 Tahun Di Resosialisasi Argorejo Semarang. [Tesis]. Fakultas Kesehatan, Universitas Dian Nuswantoro. UDiNus Repository. http://eprints.dinus.ac.id/id/eprint/6724

Handayani, R., Maria Tuntun, Misbahul Huda. 2013. Faktor-Faktor Yang Berhubungan Dengan Kejadian IMS di Pantai Harapan Panjang Bandar Lampung. Jurnal Analis Kesehatan 2( 1), 243-249

Holmes, N.O. 2005. Sifilis. Jakarta: Balai Penerbitan FKUI.

Kementerian Kesehatan RI. 2011. Pedoman Nasional Penanganan Infeksi Menular Seksual. Direktorat Pengendalian Penyakit dan Penyehatan Lingkungan. Jakarta: Kementerian Kesehatan RI.

Naully, P. G., Romlah, S. 2018. Prevalensi HIV dan HBV pada Kalangan Remaja. Jurnal Kesehatan, 9(2), 280-288. http://ejurnal.poltekkes-tjk.ac.id/index.php/JK

Notoatmodjo, S. 2003. Promosi Kesehatan dan dan Teori-Teori Kesehatan. Jakarta: Rineka Cipta.

Sridana, M.E., Agung Wiwiek Indrayani. 2014. Karakteristik Pasien Infeksi Menular Seksual (IMS) Pada Puskesmas di Denpasar Selatan periode Januari-Juni Tahun 2012. E-Jurnal Medika Udayana, Vol 3 no 12. https://ojs.unud.ac.id/index.php/eum/article /view/11948.

Santoso, EB, Antono Suryoputro, Bagoes Widjanarko. 2015. Analisis Faktor-faktor yang berhubungan dengan perilaku seks beresiko HIV/AIDS dan IMS pada remaja 
di Kabupaten Banyuwangi. Digital Library. Surakarta: Stikes Kusuma Husada. digilib.stikeskusumahusada.ac.id/files/disk 1/.../01-gdl-ekobudisan-1598-1-ekobudio.pd.

UNESCO. 2012. Buku Suplemen Bimbingan Teknis Kesehatan Reproduksi: Infeksi
Menular Seksual dan HIV/AIDS. Jakarta: BKKBN bekerjasama dengan UNESCO. http://unesdoc.unesco.org/images/0022/00 2295/229599ind.pdf

WHO. 2016. Reproductive Health. www.who.int/mediacentre/factsheets/fs110 len/ 